Prepared in cooperation with the

Connecticut Department of Energy and Environmental Protection

\title{
User Guide for the Connecticut Streamflow and Sustainable Water Use Estimator (CT SSWUE- Version 1.0) Computer Program
}

Open-File Report 2018-1163 



\section{User Guide for the Connecticut Streamflow and Sustainable Water Use Estimator (CT SSWUE-Version 1.0) Computer Program}

By Gregory E. Granato and Sara B. Levin

Prepared in cooperation with the

Connecticut Department of Energy and Environmental Protection

Open-File Report 2018-1163 


\title{
U.S. Department of the Interior \\ RYAN K. ZINKE, Secretary
}

\author{
U.S. Geological Survey \\ James F. Reilly II, Director
}

U.S. Geological Survey, Reston, Virginia: 2018

For more information on the USGS - the Federal source for science about the Earth, its natural and living resources, natural hazards, and the environment-visit https://www.usgs.gov or call 1-888-ASK-USGS.

For an overview of USGS information products, including maps, imagery, and publications,

visit https://store.usgs.gov.

Any use of trade, firm, or product names is for descriptive purposes only and does not imply endorsement by the U.S. Government.

Although this information product, for the most part, is in the public domain, it also may contain copyrighted materials as noted in the text. Permission to reproduce copyrighted items must be secured from the copyright owner.

Suggested citation:

Granato, G.E., and Levin, S.B., 2018, User guide for the Connecticut Streamflow and Sustainable Water Use Estimator (CT SSWUE—version 1.0) computer program: U.S. Geological Survey Open-File Report 2018-1163, 7 p., https://doi.org/10.3133/ofr20181163.

ISSN 2331-1258 (online) 


\section{Acknowledgments}

This report and the accompanying software were developed by the U.S. Geological Survey (USGS) in cooperation with the Connecticut Department of Energy and Environmental Protection (CT DEEP). Teresa K. Gagnon, Corinne Fitting, and Melissa Czarnowski of the CT DEEP betatested the Connecticut Streamflow and Sustainable Water Use Estimator (CT SSWUE) version 1.0 software and provided questions and comments that improved the software and this manual. Elizabeth Ahearn, Scott Olson, and Tomas Smieszek of the USGS helped beta-test the software and provided questions and comments that improved it. Jeffrey Barbaro, Tomas Smieszek, Marla Stuckey, Jonas Casey-Williams, Peter Weiskel, Matt Ely, and Kevin Breen provided editorial and technical reviews that improved this report. 



\section{Contents}

Acknowledgments ……...................................................................................................................

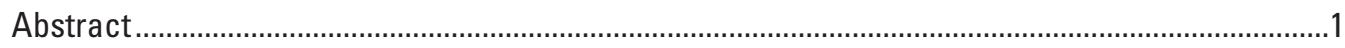

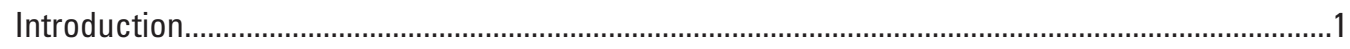

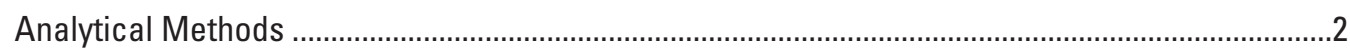

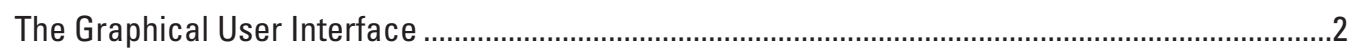

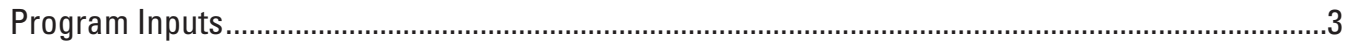

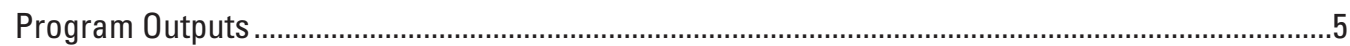

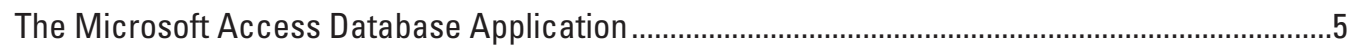

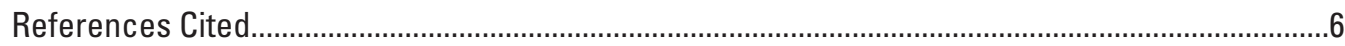

\section{Figures}

1. Flowchart showing the sequence for navigating through the graphical user interface of the Connecticut Streamflow and Sustainable Water Use Estimator to import data, specify flow targets, and calculate flow durations, flow records, yields, and output statistics for unaltered flow and water-use-adjusted streamflows....2

2. Screen capture showing the detailed information available to the user on an example form within the Connecticut Streamflow and Sustainable Water Use Estimator

\section{Tables}

1. Summary of basin-property variables for input into the Connecticut Streamflow and Sustainable Water Use Estimator, version 1.0.

2. Summary of options for data output from the Connecticut Streamflow and Sustainable Water Use Estimator. 


\section{Conversion Factors}

U.S. customary units to International System of Units

\begin{tabular}{lll}
\hline \multicolumn{1}{c}{ Multiply } & By & \multicolumn{1}{c}{ To obtain } \\
\hline inch (in.) & 2.54 & centimeter $(\mathrm{cm})$ \\
foot (ft) & 0.3048 & meter $(\mathrm{m})$ \\
mile (mi) & 1.609 & kilometer $(\mathrm{km})$ \\
square mile $\left(\mathrm{mi}^{2}\right)$ & 2.590 & square kilometer $\left(\mathrm{km}^{2}\right)$ \\
inch per hour $(\mathrm{in} / \mathrm{h})$ & 0.0254 & meter per hour $(\mathrm{m} / \mathrm{h})$ \\
\hline
\end{tabular}

\section{Abbreviations}

CSV comma-separated values

CT SSWUE Connecticut Streamflow and Sustainable Water Use Estimator

GUI graphical user interface

HyDroDSS hydrologic drought decision support system

USGS U.S. Geological Survey

VBA Visual Basic for Applications 


\title{
User Guide for the Connecticut Streamflow and Sustainable Water Use Estimator (CT SSWUE- Version 1.0) Computer Program
}

\author{
By Gregory E. Granato and Sara B. Levin
}

\begin{abstract}
This report is a user guide for the Connecticut Streamflow and Sustainable Water Use Estimator (CT SSWUE) computer program (version 1.0). The CT SSWUE was developed by the U.S. Geological Survey in cooperation with the Connecticut Department of Energy and Environmental Protection to provide a planning-level decision-support tool designed to help decision makers estimate daily mean streamflows and selected streamflow statistics to assess sustainable water use at ungaged sites in Connecticut. The CT SSWUE provides estimates of unaltered streamflow (which is assumed to occur in the absence of any water withdrawals or wastewater discharges and with minimal human development), net streamflow alterations caused by water use, water-use-adjusted streamflow, streamflow yields (estimated unaltered streamflow minus user-defined flow targets), and estimates of the accuracy and uncertainty of estimated unaltered streamflow. The CT SSWUE uses basin characteristics and water-use volumes (water withdrawals and wastewater-return flows) obtained from the U.S. Geological Survey online StreamStats application to estimate the unaltered and water-use-adjusted streamflows. The CT SSWUE is a database application with a graphical user interface developed by using Visual Basic for Applications with the 32-bit version of Microsoft Access. The graphical user interface is designed to include full documentation for users: an introductory instruction form and onscreen help within each interactive form, including explanation buttons, context-sensitive help buttons, and tool-tip and status-bar messages.
\end{abstract}

\section{Introduction}

Sustainable water-use estimator tools provide planninglevel estimates of streamflow at a selected site and the potential effects of water use on that streamflow (Archfield and others, 2010; Levin and others, 2018). This information is needed to help decision makers balance human water needs with the instream flows needed to sustain healthy ecosystems.
The Connecticut Streamflow and Sustainable Water Use Estimator (CT SSWUE) computer program was developed by the U.S. Geological Survey (USGS) in cooperation with the Connecticut Department of Energy and Environmental Protection to provide a planning-level decision-support tool designed to help decision makers estimate daily mean streamflows and selected streamflow statistics to assess sustainable water use at ungaged sites in Connecticut (Granato and Levin, 2018). Planning-level estimates commonly are defined as the results of analyses used to evaluate broad policy measures or alternative management measures; planning-level estimates are recognized as including substantial uncertainties (commonly orders of magnitude) in all aspects of the decision process (Barnwell and Krenkel, 1982; Granato, 2013, 2014). The CT SSWUE provides estimates of unaltered streamflow (unaltered streamflow is the estimated daily mean streamflow in a drainage basin in the absence of any water withdrawals or wastewater discharges and with minimal human development), net streamflow alterations caused by water use, water-use-adjusted streamflow, streamflow yields (estimated unaltered streamflow minus user-defined flow targets), and estimates of the accuracy and uncertainty of estimated unaltered streamflow. The CT SSWUE uses basin characteristics and water-use volumes obtained from the USGS online StreamStats application (Ries and others, 2017; https://water.usgs.gov/osw/streamstats/) to estimate the unaltered and water-use-adjusted streamflows; the user must first run the StreamStats application to get the data and then run the CT SSWUE to use the data.

This report is a guide to describe the implementation and use of the CT SSWUE computer program (Granato and Levin, 2018), which is available on the USGS ScienceBase-Catalog website (https://doi.org/10.5066/P9V6ARUS). The theory and application of methods of estimating streamflow and sustainable water use are described by Levin and others (2018). This user guide provides brief overviews of the numerical methods, graphical user interface (GUI) of the CT SSWUE, and logistics for implementation and use of the Microsoft Access database application. It does not include step-by-step details on how to use the program because onscreen help features within the GUI provide this information so that users can learn the software as they navigate the interface. 


\section{Analytical Methods}

The CT SSWUE uses analytical methods that were developed and used for the original Massachusetts SustainableYield Estimator (MASYE version 1.0) (Archfield and others, 2010) and the Rhode Island hydrologic drought decision support system (HyDroDSS version 1.0) (Granato, 2014). The application of these methods for the CT SSWUE is described in more detail by Levin and others (2018). The CT SSWUE calculates percentiles of daily mean flow by using regression on basin characteristics; distributes these percentiles of daily mean flow over a long-term time series by using an index-streamgage record; calculates available yields of daily mean streamflow by using user-defined flow targets; calculates water-use-adjusted values of daily mean streamflow by using water-use data; calculates estimates of the accuracy and uncertainty of estimated unaltered streamflow; and calculates selected streamflow statistics by using standard statistical methods. These methods are described in detail by Archfield and others (2010), Granato (2009, 2014), Granato and others (2017), Granato and Levin (2018), Farmer and Levin (2018), and Levin and others (2018). These methods also are described within the explanations and context-sensitive help available within the CT SSWUE GUI.

\section{The Graphical User Interface}

The GUI has 15 forms. A form is a window that appears within the Microsoft Access database GUI and consists of text and controls, such as text boxes, buttons, and pull-down menus (known as combo-boxes), that provide the means for entering or importing data, calculating streamflow and streamflow statistics, and exporting results. The GUI includes an opening-screen form, an instruction form, a main-menu form, six user-input forms, two forms to track the progress of lengthy calculations, two output-graphing forms, a text output form, and a file-specification form. The opening screen displays the agency logos while the application loads. The instruction form provides information about the program and its use. The main menu appears once the user continues beyond the instruction form. The main-menu form has a series of buttons on the left that provide information about the application and a series of action buttons on the right to carry out an analysis or to exit the application. After the main menu, the user proceeds through the input forms to define an analysis in the following order (fig. 1):

1. Analysis-definition form (Analysis input) —input descriptive information about the simulation

2. Input basin characteristics form (Site input) - input or import basin characteristics, which are generated in StreamStats, for the site of interest

3. Index-streamgage selection form (Streamgage selection) - view information about the computer-selected index streamgage, or select a different index streamgage

4. Flow-targets form (Flow-target selection) - user can select or define new streamflow targets

5. Water-use volumes form (Water-use input) - import monthly water-use information from StreamStats or user-created file

6. Streamflow-estimator calculation and output form (Flow calculation and Output selection) - select the desired output metrics, calculate statistics and uncertainty multipliers, and select the desired formats

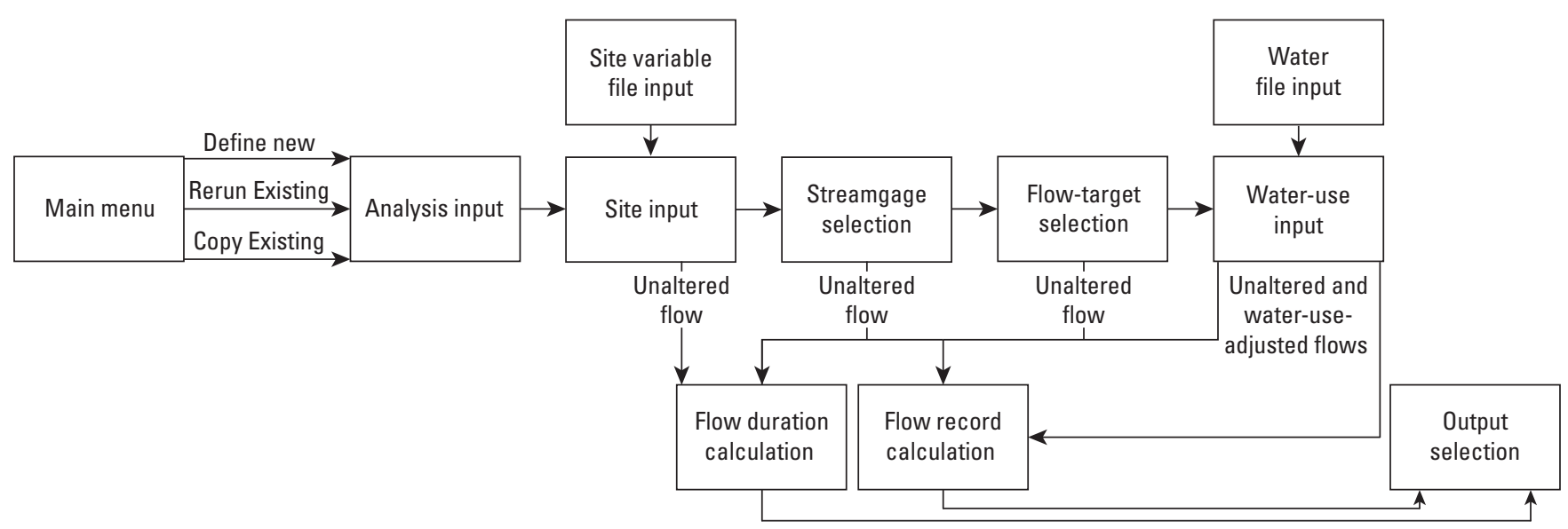

Figure 1. The sequence for navigating through the graphical user interface of the Connecticut Streamflow and Sustainable Water Use Estimator to import data, specify flow targets, and calculate flow durations, flow records, yields, and output statistics for unaltered flow and water-use-adjusted streamflows. 
To use this computer program, click through the user interface and enter (or import) the required information on each form. The flowchart (fig. 1), which is available within the GUI, shows the order of operations rather than the actual forms. To use the application, start at the main menu and proceed through the forms to define an analysis, input the properties of the site of interest, select an index streamgage, specify flow targets, input water-use information, calculate unaltered and water-use-adjusted flows, and output various statistics. As the flowchart indicates, flow durations can be calculated from each form after the properties of the site of interest have been defined. A flow-record time series can be calculated once an index streamgage has been selected, and water-use-adjusted flows can be calculated once the water-use information has been imported. After the unaltered or water-use-adjusted flows are calculated, the resulting flow statistics can be output in various formats from the final form.

The program provides four opportunities to calculate output streamflows (fig. 1). Some of these options bypass subsequent data-input forms and can be used to quickly evaluate scenarios without requiring the full sustainable-yield computations. These options are the following:

1. View Unaltered Flow Durations-This button on the input basin characteristics form allows the user to view the flow-duration curve for estimated daily unaltered flow (estimated streamflows in the absence of water-use effects and flow regulation) and evaluate the potential effect of basin characteristics on estimated streamflow values without completing the other input forms, which can take several minutes. The option to calculate estimated flow durations from this form may be especially important if the values of one or more properties of the selected basin are outside the ranges used to develop the regression equations.

2. View Unaltered Streamflows-This button on the indexstreamgage selection form provides the opportunity to quickly evaluate the potential effect of the indexstreamgage selection on the time series of estimated flow values (estimated streamflows in the absence of water-use effects) without having to enter or select flow targets, import water-use data, and calculate the wateruse alterations.

3. View Target Flows-This button on the flow-targets form provides the opportunity to quickly evaluate the potential effect of the selected flow targets on the calculated basin yields without having to import water-use data and calculate the water-use alterations.

4. Calculate Adjusted Streamflows-This button on the water-use volume input form allows users to view and compare estimated unaltered, water-use-adjusted, and target streamflows.

Detailed information on the individual controls on a form is available as text on the form, in the explanations for each form, and in the context-sensitive help buttons associated with the individual controls on each form (fig. 2). The "Explanation" button on each form provides relevant information about the form. The "?" buttons next to each input field or button provide additional, context-sensitive help. Each object also has status bar and tool-tip text explanations. The status bar text explanations appear in the lower left corner of the database window. The tool-tip text explanations appear if the mouse cursor is held over the object without clicking on it. The GUI is designed to provide visual cues that facilitate its use. Related form controls are grouped within rectangles. For example, the navigation menu, used to proceed from form to form through the application, is on the bottom of each form and consists of buttons surrounded by a green rectangle (fig. 2). Related controls also are grouped by tabbed pages on some forms; the controls appear when the tab is clicked on.

\section{Program Inputs}

The application has four sets of inputs (fig. 1). The analysis information, which is used to name and document each CT SSWUE analysis, is manually entered on the analysis-definition input form. The basin characteristics (table 1), which are used in the regression equations to calculate the unaltered flows, can be entered on the basin-characteristics input form or imported from a tab-delimited text or comma-separated values (CSV) file by using the input option on this form. The flowtargets, which are used to calculate the streamflow yields, are manually entered on the flow-targets form. The monthly-flow targets can be entered as flow thresholds or a percentage of the unaltered flow. Once a set of flow targets has been defined, it can be selected for all subsequent analyses. The wateruse data, which are used to calculate the water-use-adjusted streamflows, are imported from a tab-delimited text or CSV input file on the water-use volume input form. Water-use data are imported rather than manually entered because the wateruse datasets are large and complex, and the manual-entry process is prone to data-entry errors.

The basin characteristics and water-use data are obtained from the StreamStats interface described by Ries and others (2017). The basin characteristics can be obtained as follows:

1. Open StreamStats, which is currently (2018) available at https://streamstats.usgs.gov/ss/.

2. Navigate to the point of interest by clicking or zooming within the map, or by entering latitude and longitude coordinates or a geographic place name on the left menu. If the place-name option is used, StreamStats will provide autocomplete options as the local place name is entered. If the correct autocomplete option appears, click on the name to zoom to the desired location.

3. Select the "Connecticut" State study area on the left menu.

4. Zoom in to at least level 15, at which the stream-centerline pixels are visible. 


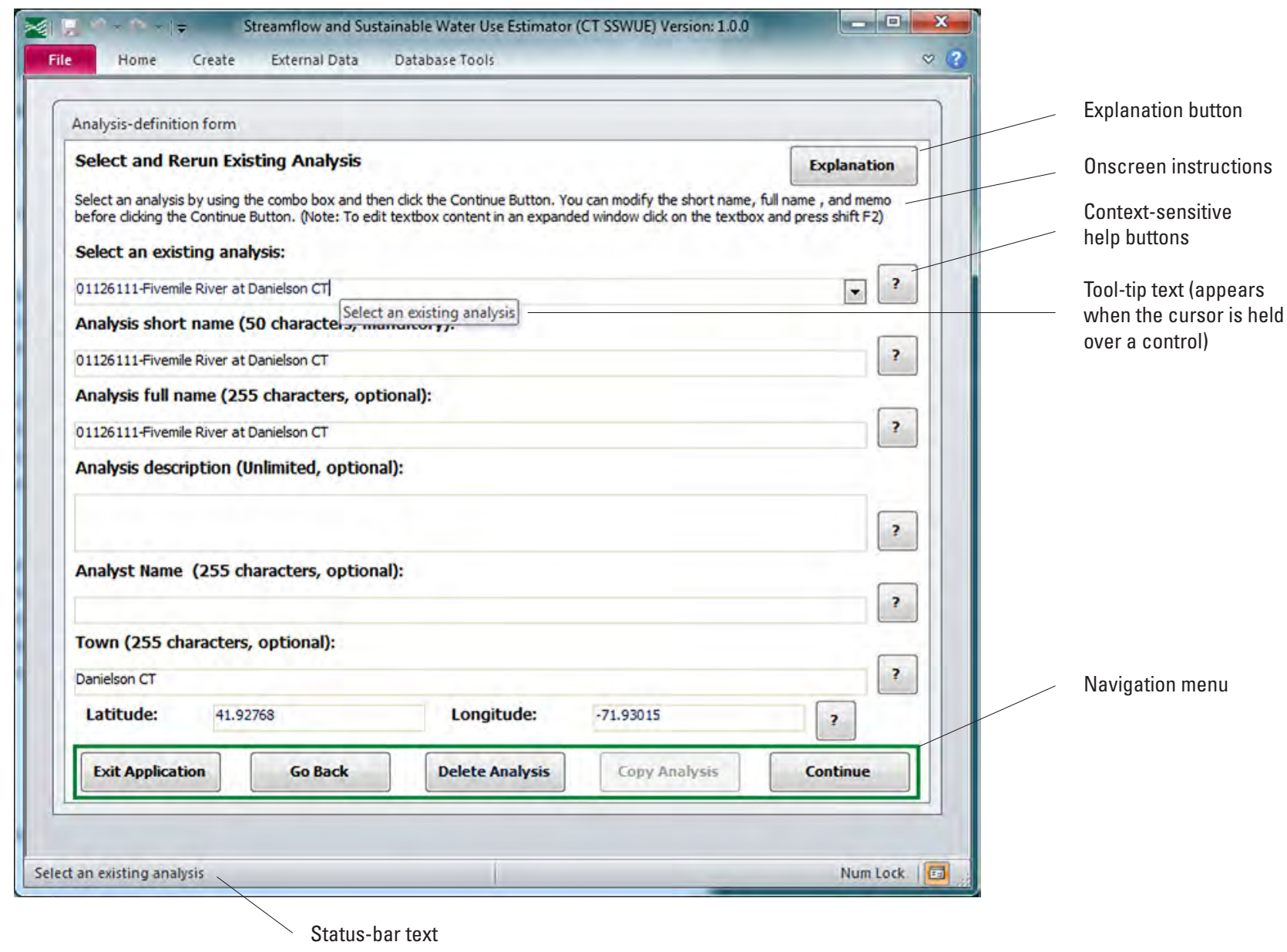

Figure 2. The detailed information available to the user on an example form within the Connecticut Streamflow and Sustainable Water Use Estimator.

5. Click the "Delineate" button on the left menu and then click on a stream-centerline pixel.

6. Once the basin is properly delineated, click the "Continue" button on the left menu, and select the "Basin
Characteristics" pulldown arrow to open the basin characteristics menu.

7. Click the "Select All Basin Characteristics" button on the left menu and then scroll down and click the "Con-

Table 1. Summary of basin-property variables for input into the Connecticut Streamflow and Sustainable Water Use Estimator, version 1.0 .

\begin{tabular}{|c|c|c|c|}
\hline Variable & $\begin{array}{l}\text { StreamStats } \\
\text { abbreviation }\end{array}$ & Description & Unit \\
\hline Drainage area & DRNAREA & Area that drains to a point on a stream & Square miles \\
\hline Average annual precipitation & MAPM & Mean annual precipitation, basin average & Inches \\
\hline Total length of mapped streams in basin & STRMTOT & Total length of all mapped streams $(1: 24,000$-scale $)$ in the basin & Miles \\
\hline \multicolumn{4}{|c|}{ Location variables } \\
\hline X-location at the outlet of the basin & CENTROIDX & Basin centroid horizontal (x) location in State Plane coordinates & Feet \\
\hline Y-location at the outlet of the basin & CENTROIDY & Basin centroid vertical (y) location in State Plane coordinates & Feet \\
\hline
\end{tabular}


tinue" button. (When the basin characteristics are later imported into the CT SSWUE, the application will filter the output file for the necessary basin-property variables.)

8. Once StreamStats has calculated the basin characteristics, click the "Continue" button below "Basin Characteristics Report" to launch the report window.

9. Once the report window appears in StreamStats, scroll to the bottom and click the "Download CSV" button, which will save a file named "data.csv" to the user's downloads folder. Rename the file and move it to the user-generated CT SSWUE analysis folder by using the Microsoft Windows GUI. Use the CT SSWUE application to open the file from either folder. However, moving and renaming the file prevents it from being overwritten in a future StreamStats session.

The water-use data can be obtained from StreamStats as follows:

10. From step 9, click on the "Identify a Study Area" banner on the left menu, then click the "Check For Water Use" button. Using the default dates, click the "Get Water Use" button on the pop-up window.

11. Click the "Water Use Table" tab on the pop-up "Study Area Water Use Summary" window.

12. Click the "Download" button on this tab and select the "Source CSV" option. This will save a "wateruseSummaryBySource.csv" file, which can be imported into the CT SSWUE application by using the water-use volumes form (fig. 1). If the "Table CSV" option is selected in StreamStats, then the "wateruseSummary.csv" file is downloaded instead; this file does not include the data that are used for the CT SSWUE analysis, and it will not be read properly.

Detailed directions for importing these files also are available on the input basin characteristics (Site input) and Wateruse volumes (Water-use input) forms (fig. 1) within the CT SSWUE.

\section{Program Outputs}

The application produces tables of daily mean flows, 7-day low flows, and monthly flows (table 2). Outputs are viewed or exported by using the output-selection forms (fig. 1). The estimated record of daily flows and daily-flow statistics can be examined and exported in text files, an Access-query format, or graphs. Outputs in the Access-query format and the graphs can be viewed within the application or exported. The text files of daily-flow values must be exported because they are too long to be viewed within the GUI. The 7-day low flows and estimates of the 7-day 10-year low flow, which is the 7-day low flow with a 10 percent chance of being
Table 2. Summary of options for data output from the Connecticut Streamflow and Sustainable Water Use Estimator.

\begin{tabular}{lcccc}
\hline \multirow{2}{*}{ Flow category } & \multicolumn{4}{c}{ Output } \\
\cline { 2 - 5 } & $\begin{array}{c}\text { Flow } \\
\text { durations }\end{array}$ & $\begin{array}{c}\text { Time } \\
\text { series }\end{array}$ & Statistics & Uncertainty \\
\hline $\begin{array}{l}\text { Daily flows } \\
\begin{array}{c}7-\text { day low } \\
\text { flows }\end{array}\end{array}$ & Yes & Yes & Yes & Yes \\
$\begin{array}{c}\text { Monthly } \\
\text { flows }\end{array}$ & No & Yes & Yes & No \\
\hline
\end{tabular}

equal to or less than the given value in any given year, can be examined and exported in a text-file format. Monthly-flow statistics can be examined and exported in a text-file format. By default, all these text-file outputs echo all the application inputs, unless the user decides to deselect the option to export the input values. Uncertainty multipliers (Farmer and Levin, 2018; Levin and others, 2018) also can be examined and exported in a text-file format. With the exception of the daily flows, all the text-file outputs can be copied as text from the output form or saved in text-file format from the output form.

The output files are written as tab-delimited ASCII text files that can be imported into many software packages. This file format begins with comment lines that describe the content of the file, the analysis-specification options, and the outputvalue columns. A pound symbol (\#) in the first character location of each line denotes these comment lines. The comments are followed by a line that lists a variable name for each type of output value in the file. These lines of comments and variable names document program outputs in a meaningful and efficient format. The remaining output lines in the text files contain the numerical results of the analysis. The tab-delimited format of the numerical-result output tables is designed to be copied and pasted into spreadsheet programs, graphing packages, statistical software, and word-processing tables. This output is designed to facilitate postmodeling analysis and presentation of results.

\section{The Microsoft Access Database Application}

The CT SSWUE is a database application with a graphical user interface (GUI) developed by using Visual Basic for Applications (VBA) with the 32-bit version of Microsoft Access. The CT SSWUE was developed as a database application because this type of application can store input analyses to facilitate repeatability of results, scenario testing, and sensitivity analyses (Granato, 2013, 2014). A database application can be deployed and used in several ways. The CT SSWUE is available as an uncompiled database file (CT-SSWUEV1.0.0.accdb), a compiled database file for future modification 
and use (CT-SSWUE-V1.0.0.accde), and a compiled-database installation file (CT-SSWUE-V1.0.0.exe). The uncompiled database file allows for user customization and future upgrades. The compiled database file provides a standard version of the application with stable VBA object-library references that runs faster than the uncompiled version. The compiled-database installation file provides a standard version of the application that runs in a controlled environment. This installed version will work on systems without compatible versions of the Microsoft Office software. To install the compiled version of the CT SSWUE, copy the database installation file (CT-SSWUE-V1.0.0.exe) to the user's computer and run the installation file, which uses standard Microsoft conventions for software installation. Administrative privileges are required for the installation. The CT SSWUE database files are available, along with the installation file and a data dictionary, on the USGS ScienceBase website (Granato and Levin, 2018).

The CT SSWUE was developed by using the 32-bit version of Microsoft Office because this version is the default and recommended version of Office for installation and use by most users (Microsoft Corporation, 2016, 2018; 404 Tech Support Inc, 2017). Microsoft recommends the use of the 32-bit version of Office and has set that version as the default installation so that most users will have files and applications that are compatible with other Office users and third-party applications. Microsoft states that only a very few advanced users with extremely large file sizes would need a 64-bit version of Office (Microsoft Corporation, 2016, 2018; 404 Tech Support Inc, 2017). If a user must have a 64-bit version of the CT SSWUE, then they may use the decompiled version of the 32-bit database (CT-SSWUE-V1.0.0.accdb) to compile a 64-bit version. To do this, copy the application to a 64-bit version of Microsoft Access, compact and repair the database, and then compile the code to catch any errors or broken references. Once the conversion issues are resolved, recompile the database for daily use. Keep an uncompiled 64-bit version for future updates.

\section{References Cited}

404 Tech Support Inc, 2017, 32-bit Office is still recommended for 64-bit Windows: 404 Tech Support web page, accessed May 5, 2018, at https://www.404techsupport.com/2017/01/16/32bit-office64bit-windows/.

Archfield, S.A., Vogel, R.M., Steeves, P.A., Brandt, S.L., Weiskel, P.K., and Garabedian, S.P., 2010, The Massachusetts Sustainable-Yield Estimator-A decision-support tool to assess water availability at ungaged stream locations in Massachusetts: U.S. Geological Survey Scientific Investigations Report 2009-5227, 41 p. plus CD-ROM. [Also available at https://pubs.er.usgs.gov/publication/sir20095227.]

Barnwell, T.O., Jr., and Krenkel, P.A., 1982, Use of water quality models in management decision making: Water Science and Technology, v. 14, no. 9-11, p. 1095-1107.

Farmer, W.H. and Levin, S.B., 2018, Characterizing uncertainty in daily streamflow estimates at ungauged locations for the Massachusetts Sustainable Yield Estimator: Journal of the American Water Resources Association, v. 54, no. 1, p. 198-210., accessed February 2018 at 10.1111/17521688.12603 .

Granato, G.E., 2009, Computer programs for obtaining and analyzing daily mean streamflow data from the U.S. Geological Survey National Water Information System web site: U.S. Geological Survey Open-File Report 2008-1362, 123 p. on CD-ROM. [Also available at https://pubs.usgs.gov/of/2008/1362/.]

Granato, G.E., 2013, Stochastic empirical loading and dilution model (SELDM) version 1.0.0: U.S. Geological Survey Techniques and Methods, book 4, chap. C3, 112 p. on CDROM. [Also available at https://pubs.usgs.gov/tm/04/c03/.] 
Granato, G.E., 2014, Hydrologic Drought Decision Support System (HyDroDSS): U.S. Geological Survey Open-File Report 2014-1003, 91 p., with CD-ROM, accessed March 2014 at http://dx.doi.org/10.3133/ofr20141003.

Granato, G.E., and Levin, S.B., 2018, Connecticut Streamflow and Sustainable Water Use Estimator (CT SSWUE) application software: U.S. Geological Survey software release, https://doi.org/10.5066/P9V6ARUS.

Granato G.E., Ries, K.G., III, and Steeves, P.A., 2017, Compilation of streamflow statistics calculated from daily mean streamflow data collected during water years 1901-2015 for selected U.S. Geological Survey streamgages: U.S. Geological Survey Open-File Report 2017-1108, 17 p., accessed October 2017 at https://doi.org/10.3133/ofr20171108.

Levin, S.B., Olson, S.A., Nielsen, M.G., and Granato, G.E., 2018, The Connecticut Streamflow and Sustainable Water Use Estimator-A decision-support tool to estimate water availability at ungaged stream locations in Connecticut: U.S. Geological Survey Scientific Investigations Report 2018-5135, 34 p., https://doi.org/10.3133/sir20185135.

Microsoft Corporation, 2016, 64-bit editions of Office 2013: Microsoft Corporation web page, accessed December 16, 2017, at https://docs.microsoft.com/en-us/previous-versions/ office/office-2013-resource-kit/ee681792(v=office.15).

Microsoft Corporation, 2018, Choose between the 64-bit or 32-bit version of Office: Microsoft Corporation web page, accessed May 5, 2018, at https://support.office.com/en-us/ article/choose-between-the-64-bit-or-32-bit-version-ofoffice-2dee7807-8f95-4d0c-b5fe-6c6f49b8d261.

Ries, K.G., III, Newson J.K., Smith, M.J., Guthrie, J.D., Steeves, P.A., Haluska, T.L., Kolb, K.R., Thompson, R.F., Santoro, R.D., and Vraga, H.W., 2017, StreamStats, version 4: U.S. Geological Survey Fact Sheet 2017-3046, 4 p. [Also available at https://doi.org/10.3133/fs20173046. Supersedes USGS Fact Sheet 2008-3067.] 

For more information about this report, contact: Director, New England Water Science Center U.S. Geological Survey

10 Bearfoot Road

Northborough, MA 01532

dc_nweng@usgs.gov

or visit our website at

https://newengland.water.usgs.gov

Publishing support provided by the Pembroke Publishing Service Center 


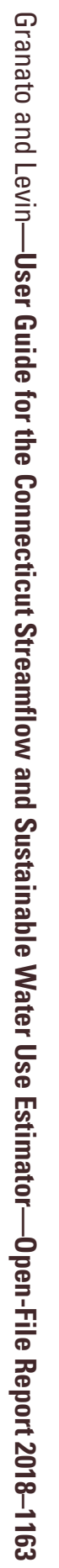

